\title{
The Digital Economy Foresight and Its Impact on the Russian Economic Environment Functioning: The Regions' Problems
}

\author{
G.E. Krokhicheva, Yu.R. Mezentseva, N.Yu. Izvarina, E.N. Sidorenko*
}

\author{
Don State Technical University, Rostov-on-Don, Russia \\ *Corresponding author.E-mail: len.sid.95@mail.ru
}

\begin{abstract}
The digital economy development in modern realities does not address the information technologies introduction in all spheres of society, their use in everyday life, the digital literacy growth, the new digital professions emergence. Ceteris paribus, the digital economy discussion includes the development of digital and informational relationships between countries, primarily regarding the economy. The article gives the digital economy phenomenon modern understanding, defines its present place in the world community. The study analyzed the UN opinion on the digital economy state for 2019. Also, the authors determined the influence degree of the digital economy - e-commerce key element on the change in the Russian economy. The analytical section of the article reflects the jobs number dynamics in the field of information technology; digital economy contribution in GDP; investing in Digital Economy
\end{abstract}

Keywords: digital economy, digital transformation, digital environment, information infrastructure, $e$ commerce, GDP information technology, online sales, online export

\section{INTRODUCTION}

An active discussion of the digital economy in the international economic space allows to identify many facets of this phenomenon, forms a number of problems and prospects for this phenomenon development.

The first reference to the digital economy was observed back in the 90s of the 20th century, and the concept of "digital economy" was introduced into scientific use in 1995 by the American scientist Nicholas Negroponte and meant a form of transition from the atoms' movement to the bits' movement. [10]

Despite the fact that the digital economy development affects the interdependent functioning of many countries, each state individually is working on its internal growth prospects for this area.

It is known, that in 2017, the Digital Economy of the Russian Federation Program was adopted, which in May 2018 was transformed into a national program. Its goal was to increase the country's competitiveness at the world level, improve the population life quality and ensure economic recovery. [3] Initially, the program was based on such areas as: information infrastructure, government regulation, digital healthcare, information security, "smart city". [1] After the transformation, 6 federal projects were identified: Digital Government, Digital Technologies, Digital Environment Normative Regulation, Human Resources for the Digital Economy, Information Infrastructure and Information Security. [7]

\section{THE FORMATION OF THE DIGITAL ECONOMY AS A SOCIAL PHENOMENON}

Thus, the 2017 Program gave a powerful impetus to the development and study of the digital economy in our country. In the course of numerous research and development in this area, the term "digital economy" understanding has been modernized. So, in the Strategy for the Information Society Development in the Russian Federation for 2017-2030, the digital economy was understood as the economic activity in which the key factor in production is digital data. Some economic studies have defined the digital economy as a part of economic relations carried out within the framework of information technology, aimed at expanding economic borders. [4, 13] Currently, the phenomenon under consideration has expanded the boundaries of its significance and implies not only a part of economic relations and the transition of production to a digital form, but also a global digital transformation of all the spheres of society. [12] At the same time, it is important to note that the initial developments in the digital economy direction included electronic commerce, the Internet of things, electronic money, while at the moment these are: innovative production, digital education, digital business models, electronic state platforms, augmented or virtual reality, new digital professions and new jobs, etc. [8]

The prerequisites for the emergence and development of the digital economy were and remain: 
Widespread Internet (over the past 10 years there has been an increase in Internet traffic by more than 40,000 GB / second) [14];

- High level of development of mobile communications;

The rapid pace of technological progress. [2,5]

Thus, the main goal of the digital economy development is to accelerate the process of economic operations by means of the automated information processes creation, implementation and modernization.

Currently, the Government has identified the following ways of developing the digital economy: ensuring the safety of life and health of the population through the use of innovative technologies, training new personnel in this field, raising the level of the country in the international rating by acquiring new knowledge. [19]

\subsection{International opinion on the digital economy development state}

The 2019 digital economy report published by the United Nations Conference on Trade and Development notes that digital data and digital platforms are driving the digital economy development. This study identifies the following components of the digital economy: the digital sector itself, the digital economy, and the digitalized economy. It is assumed that investing in these components' development will contribute to accelerating the pace of production, increasing added value, changing the number of jobs, labor automation, technological growth, market concentration, and increasing inequality. The UN analysis presents a statistical study of the digital platforms impact on the example of some popular services such as Google, Facebook, Amazon, Alibaba. It is noted that more than $90 \%$ of the countries use these platforms, and the total value of companies operating in the digital environment has a high growth rate over time (more than $60 \%$ over two years).

The key prospect for the discussed direction development, according to the authors of the report, is the data transformation into "digital intelligence", that is, a modification of digital platforms aimed at offering services to regions taking into account the needs of local users.

The main problem of such technological development, according to the United Nations representatives, is an increase in inequality and forces imbalance, and the solution to this problem is to revise some provisions of the law and develop a new competition and taxation policy. Thus, the identified problem remains open, and requires proposals and the specific measures' implementation to solve it. [14]

\subsection{Electronic commerce as a structural element of digital economy}

For a long time, at the beginning of the digital economy phenomenon emergence, the concepts of "digital economy" and "electronic commerce" were understood in many studies as a whole and were practically interchangeable. However, as mentioned earlier, the digital economy today implies a massive digital transformation, and e-commerce has become only a part of its structure. Moreover, this element plays a key role in the economic component of the phenomenon under consideration, as it means trade and other economic relations in the information infrastructure. [9]

A comprehensive analysis of the e-commerce state is regularly conducted by the Data Insight research agency The analysts' report "Internet Trading in Russia 2019" examined global Internet trading, B2C and C2C markets in Russia, online retail export, the e-commerce ecosystem, retail technologies, logistics in e-commerce, and the ecommerce market geography (Figure 1) [20].

In our opinion, the most important are the following provisions of this study.

1) The largest volume of the e-commerce market in 2019 is in China (5.1\% GDP share), Russia takes the penultimate place in this list (1.3\% GDP share). However, the market growth in Russia was noted at $21 \%$ compared to the previous year, which can be noted as a positive trend.

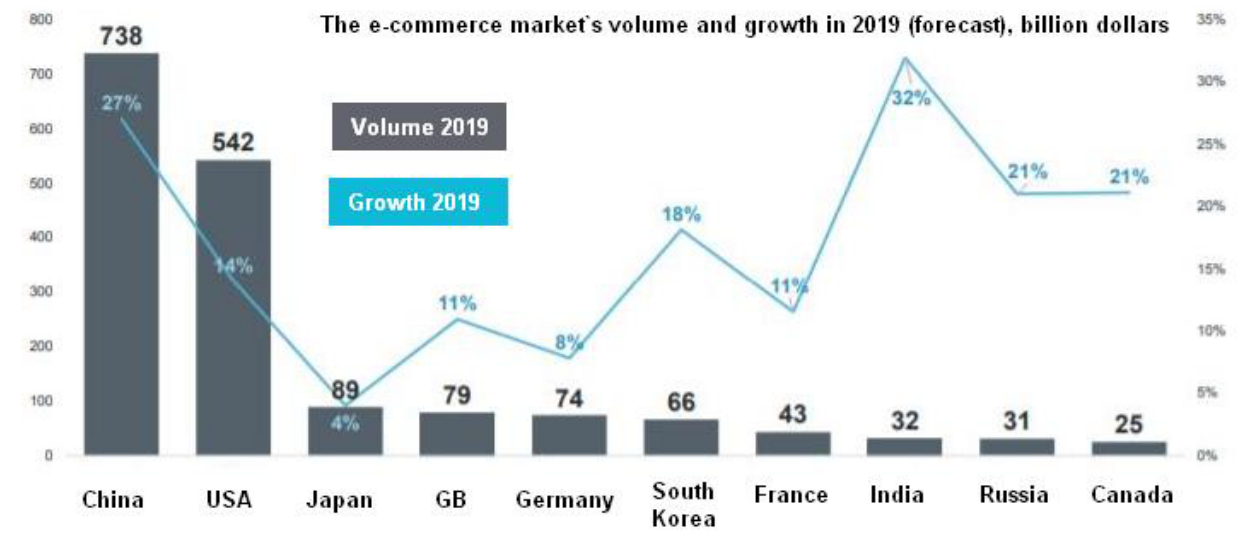

Figure 1 The e-commerce market's volume and growth in 2019 according to Data Insight [20] 
Internet trading market in Russia is growing precisely due to an increase in the number of sales with a decrease in the average check amount.

3) The research agency in the report shows the dynamics of changes in online sales in Russia from 2011 to 2019 (Figure 2). So, in general, for the indicated period, the studied indicator increased by $575 \%$.

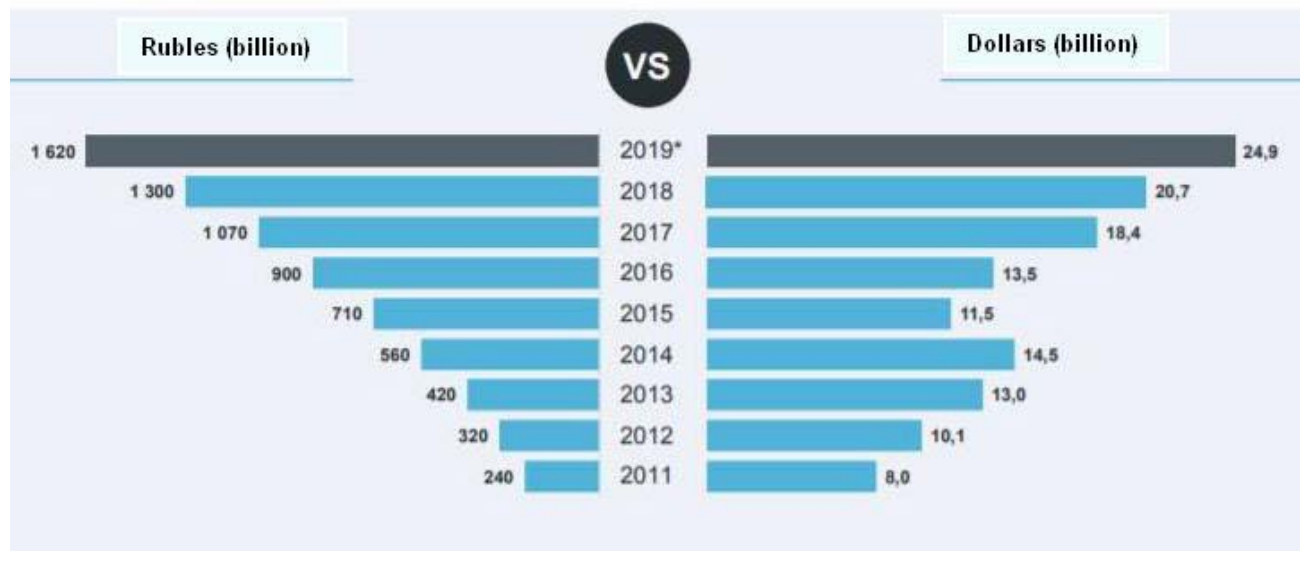

Figure 2 Dynamics of online sales in Russia according to Data Insight [20]

4) At the same time, online sales in Russia include online export. So, the analysts registered 15.7 million items for 2019 with an average check of \$ 52. And the volume of the online export market amounted to $\$ 817$ million.

5) Digital transformation did not leave aside e-commerce. So, in 2019, the e-commerce ecosystem, consisting of the following blocks was outlined and developed:

$\begin{array}{ll}- & \text { Logistics; } \\ - & \text { IT; } \\ - & \text { Assortment management; } \\ - & \text { Payments acceptance; } \\ - & \text { Trading floors; } \\ - & \text { Loyalty and marketing; } \\ - & \text { Customer acquisition; } \\ - & \text { Other }\end{array}$

The main areas of the ecosystem's development were named as:
- $\quad$ the emergence of local ecosystems around make-ups and individual directions;

- $\quad$ niche services;

- $\quad$ integration of services, offering the maximum range of services, most of which is given to third-party companies.

6) An important aspect of the analysis, reflecting the problem of the regions, in our opinion, is a summary diagram of electronic purchases by federal districts (Figure 3). More than $50 \%$ is the number of trading operations performed in the Central Federal District and the Volga Federal District. The smallest total orders, 5\% in total, are in the Far Eastern Federal District and the North Caucasian Federal District. The distribution in other districts is approximately uniform and averages about $10 \%$. A similar percentage indicates that the regions are not ready for the introduction of information technologies in everyday life and for digital transformation in general.

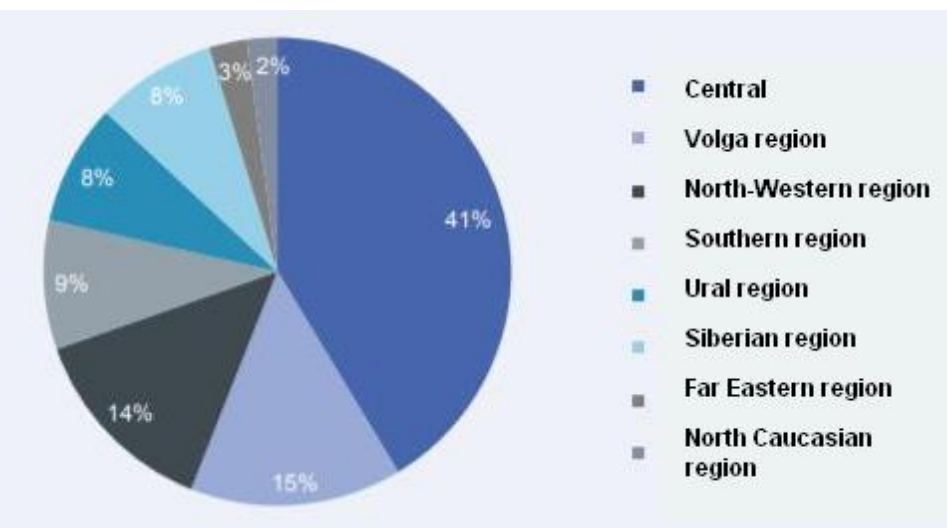

Figure 3 Distribution of online sales by the federal districts according to Data Insight 
However, it can be stated that the regional development growth in the field of digital technology is present. So, according to the data of 2017, the following dynamics of changes in the regional market volumes was observed, which is reflected in Table 1. [18]

Table 1 Regional distribution of the e-commerce market

\begin{tabular}{|c|c|c|c|c|c|c|}
\hline Region & \multicolumn{2}{|c|}{2016} & \multicolumn{2}{|c|}{2017} & \multicolumn{2}{|c|}{ Deviation (+-) } \\
\hline & $\begin{array}{l}\text { billion } \\
\text { rubles }\end{array}$ & $\begin{array}{l}\text { as \% of the } \\
\text { market } \\
\text { volume }\end{array}$ & $\begin{array}{l}\text { billion } \\
\text { rubles }\end{array}$ & $\begin{array}{l}\text { as \% of the } \\
\text { market } \\
\text { volume }\end{array}$ & $\begin{array}{l}\text { billion } \\
\text { rubles }\end{array}$ & as $\%$ \\
\hline 1 & 2 & 3 & 4 & 5 & 6 & 7 \\
\hline Moscow & 258 & 40 & 297 & 40 & 39 & 0 \\
\hline Volga region & 90 & 14 & 112 & 15 & 22 & 1 \\
\hline St. Petersburg & 58 & 9 & 82 & 11 & 24 & 2 \\
\hline Siberian region & 77 & 12 & 74 & 10 & (3) & (2) \\
\hline Central region (without Moscow) & 45 & 7 & 59 & 8 & 14 & 1 \\
\hline Ural region & 58 & 9 & 52 & 7 & (6) & (2) \\
\hline Southern region & 26 & 4 & 30 & 4 & 4 & 0 \\
\hline North-Western region (without SPB) & 19 & 3 & 15 & 2 & (4) & (1) \\
\hline Far Eastern region & 6 & 1 & 15 & 2 & 9 & 1 \\
\hline North Caucasian region & 7 & 1 & 7 & 1 & 0 & 0 \\
\hline Total & 644 & 100 & 743 & 100 & 99 & 0 \\
\hline
\end{tabular}

As it can be seen from the analysis, the largest share growth in all-Russian market was shown by the city of federal significance St. Petersburg, which increased its share from $9 \%$ to $11 \%$. Volga and Central Federal Districts also showed growth above the market average. A negative change in the indicator is observed in the Siberian, Ural and Northwestern federal districts.

The results of the study by the Data Insight agency show that consumer loyalty to the use of digital platforms, using the e-commerce example, is increasing in everyday life, therefore, the same can be said about other digital economy elements. Demand for the information platforms is increasing due to the use simplicity, time saving and technology availability. However, in terms of accessibility, the situation can be called controversial, since there are difficulties in "communicating with technology", Internet access and information literacy, and the local authorities' connection with a digital base in the regions.

\subsection{Statistical analysis of the digital economy development in the russian federation.}

1) The number of jobs. Over the past three years, the share of people employed in the field of information technology has been $2 \%$ of the total number involved in the country's economic activity, which indicates a stable progressive development of the digital component. At the same time, the number of specialists under the age of 35 in this category is $53 \%$, which suggests an innovative view on the technologies development in the future, and, as a result, a jump in the digital economy development. [17]

2) GDP. According to the Russian Federal Statistic Service first estimate, Russia's GDP for 2019 amounted to 109 trillion 361.5 billion rubles in current prices. The GDP deflator index for 2019 relative to the prices of 2018 amounted to $103.4 \%$. [16]

As mentioned above, the e-commerce market share is $1.3 \%$ in the structure of GDP, however, according to the statistical studies, the information and communication activities output is $2.3 \%$ when ranking GDP by the income source.

The study by McKinsey "Digital Russia: New Reality consulting company" predicts the changes in GDP structure. Thus, according to the company, the potential economic effect of the Russian economy digitalization will increase the country's GDP by 2025 by $4.1-8.9$ trillion rubles (in 2015 prices), which will be from 19 to 34\% of the total expected GDP growth.

3) Investing in the digital economy development. When analyzing the investments in fixed assets, according to the Federal State Statistics Service (Rosstat), it was determined that investments in the field of information and communications amounted to 601.5 billion rubles. That includes the activities in the field of information technology accounted for 32.3 billion rubles. In percentage 
2) to introduce the "digital economy" concept and to clarify the digital economy phenomenon essence in the legislation at the state level. fixed assets. And in percentage terms, by 2018, the investments increased by more than $20 \%$, which indicates the state interests focus on the information technologies' development. [6]

Domestic costs for the digital economy development also amount to more than 3 billion rubles. The percentage cost ratio by industry is presented in Table 2 .

Table 2 Distribution of internal costs for the digital economy development by industry. [15]

\begin{tabular}{|l|l|l|}
\hline $\begin{array}{l}\text { Costs of using } \\
\text { digital } \\
\text { technologies and } \\
\text { related products } \\
\text { and services }\end{array}$ & Government sector & $10,8 \%$ \\
\cline { 2 - 3 } & Higher education sector & $0,7 \%$ \\
\cline { 2 - 3 } & Nonprofit Sector & $0,4 \%$ \\
\cline { 2 - 3 } & Household sector & $36,4 \%$ \\
\hline $\begin{array}{l}\text { Costs of organizations and households to } \\
\text { acquire the digital content }\end{array}$ & $11,3 \%$ \\
\hline
\end{tabular}

\section{CONCLUSION}

Thus, by analyzing the current state of the digital economy in Russia, a number of open questions determining the development vector of this phenomenon and requiring further scientific research, both from an economic and technological point of view can be identified [11]:

1. Despite the positive dynamics of the digital transformation development and implementation, it is necessary to promote the digital economy growth. The following activities are expected to accomplish this:

to increase the level of the population digital literacy by creating informational television commercials or programs explaining the features of the introduction and application of modern information technologies in everyday life;

to create a larger number of scientific laboratories involved in the development, testing and implementation of innovative software on the basis of institutes;

- $\quad$ to increase the digital development level in the regions by means of progressive technical re-equipment.

2. In some studies, there is still confusion in the concepts of "digital economy" and "digital transformation", the separation of the digital economy into a separate category not related to the economic sphere of the society's life continues, and it is even supposed to supplant the traditional economy with this phenomenon. In this regard, 2 solutions to this problem are proposed:

1) to replace the concept of "digital economy" with "digital transformation” in the global research community

\section{REFERENCES}

[1] The program "Digital Economy of the Russian Federation”, approved by order of July 28, 2017 No. 1632

[2] Introduction to the Digital Economy / A.V. Keshelava V.G. Budanov, V.Yu. Rumyantsev and others; under the general ed. A.V. Keshelava. Chief digital consultant I.A. Zimnenko. M.: RSRI Geosystem, 2017.

[3] Abdrakhmanova G.I., Kovaleva G.G. Digital Economy: Digital Skills of the Population. - M.: HSE, 2017.

[4] Aptekman A., Kalabin V. et al. "Digital Russia: a new reality” - Digital / McKinsey, 2017. - DOI: http://www.tadviser.ru/images/c/c2/Digital-Russiareport.pdf

[5] Volovik E. Digital tax. Is there a digital economy? DOI: xn-7sbbaj7auwnffhk.xn-p1ai / article / 28427

[6] Gokhberg L.M., Kovaleva G.G., Suslov A.B. Gross domestic costs for the digital economy development in 2018 - National Research University Higher School of

https://issek.hse.ru/news/317281408.html

[7] Ilchenko A.N., Ilchenko K.A. Digital economy as the highest stage in the information and communication technologies development // Modern High-Tech Technologies. 2018 - DOI:

https://cyberleninka.ru/article/n/tsifrovaya-ekonomikakak-vysshaya-stupen-razvitiyainfokommunikatsionnyh-tehnologiy.

[8] Krokhicheva G.E., Sidorenko E.N., Pobivanets T.V., Panova A.A. Problems and features of Russia's transition to the digital economy functioning. Management Accounting. 2019.No 6. pp. 17-24.

[9] Krokhicheva G. E., Sidorenko E. N. E-commerce as a structural element of the digital economy // Scientific electronic journal "Matrix of Scientific Knowledge" No. 12/2017 - DOI: https://auspublishers.com.au/ru / storage / view / 26501

[10] Lapidus. L.V. The digital economy. Management of electronic business and electronic commerce / L.V. Lapidus-M.: INFRA-M, 2019.-382 p. Economics DOI: 
248 p. - DOI:

https://www.hse.ru/data/2019/06/25/1490054019/ice20 19.pdf

[16] Russia in numbers. 2019: A Brief Statistical Digest / Federal State Statistics Service (Rosstat). - M., 2019. DOI:

https://www.hse.ru/data/2019/06/25/1490054019/ice20 19.pdf

[17] Digital economy: 2020: a brief statistical compilation / G.I. Abdrakhmanova, K.O. Vishnevsky, L.M. Gokhberg et al.; National researched University “Higher School of Economics". - M.: HSE, 2020. - 112 p. - DOI:

https://issek.hse.ru/mirror/pubs/share/323871553

[18] The official website of the Federal State Statistics Service (Rosstat). - DOI: https://www.gks.ru/

[19] News economic portal. - DOI: https://webeconomy.ru/

[20] Portal of a research agency in the e-commerce market. - DOI: https://datainsight.ru/ 